\title{
Association between Decreased Plasma Folate Levels and MTHFR C677T, and MTRR A66G Gene Polymorphisms as Determinants for Elevated Total Homocysteine Concentrations in Pregnant Women
}

\author{
Cang-Sang Song ${ }^{1 \#}$, Wen-Bin Song ${ }^{1 \#}$, Jin-Ying Bao ${ }^{1}$, Jing Luo ${ }^{2}, \mathrm{Xin} \mathrm{Zuo}^{2}, \mathrm{Ni} \mathrm{An}^{3}$, and Yang Zhang ${ }^{{ }^{*}}$ \\ ${ }^{1}$ Department of Pharmacy, First People's Hospital of Kunming, Kunming, Yunnan, People's Republic of China \\ ${ }^{2}$ Department of Obstetrics, First People's Hospital of Kunming, Kunming, Yunnan, People's Republic of China \\ ${ }^{3}$ Department of Pharmacy and Chemistry, Dali University, Dali, Yunnan, People's Republic of China
}

*Corresponding author:Yang Zhang, Department of Pharmacy, First People's Hospital of Kunming, Beijing Road 1228\#, Kunming, Yunnan, 650224, People's Republic of China, Tel: 0871-67390624; E-mail: zhangyang147890@163.com

\#These authors contributed equally to this work.

Rec Date: March 20, 2018; Acc Date: March 27, 2018, 2018; Pub Date: March 30, 2018

Copyright: (c) 2018 Song C, et al. This is an open-access article distributed under the terms of the Creative Commons Attribution License, which permits unrestricted use, distribution, and reproduction in any medium, provided the original author and source are credited.

\section{Abstract}

Aims: The aims of this paper were to examine the association between gene polymorphisms of methylenetetrahydrofolate reductase (MTHFR) C677T and methionine synthase reductase (MTRR) A66G with levels of plasma folate and tHcy.

Methods: Peripheral venous blood samples were obtained from 143 pregnant women, who had been fasted for more than 10 hours. Plasma tHcy and folate concentrations were measured in plasma specimens. The genotypes for polymorphisms were identified by the PCR-restriction fragment length polymorphism (RFLP).

Results: Our results demonstrated that MTHFR 677T allele was the predictors of plasma folate levels in pregnant women. While MTHFR 677TT genotype and MTRR 66G allele were the predictors of plasma tHcy concentrations. Plasma folate levels were negatively correlated with tHcy concentrations (Pearson's correlation coefficient $r=-0.358$, $p=0.000012$ ). With the increase of gestational weeks, the levels of plasma folate was first risen and then fall, whereas, there was a downtrend between gestational weeks and tHcy levels.

Conclusion: Plasma folate status and total homocysteine level associated with MTHFR C677T and MTRR A66G gene polymorphisms in pregnant women. According to our study, the pregnant women of homozygous mutation of MTHFR 677TT and/or MTRR 66GG genes generally have lower levels of folate. Therefore, we recommend that pregnant women with $677 \mathrm{TT}$ and $66 \mathrm{GG}$ genotypes should supplement the appropriate dosage of folic acid based on their genotypes.

Keywords: Folic acid; Neural tube defects; Methylenetetrahydrofolate reductase (MTHFR); Methionine synthase reductase (MTRR); Genotype; Homocysteine; Gene polymorphism

\section{Introduction}

Folic acid, which known as vitamin B9 or folate is an essential nutrient, is required for a series of biochemical pathways included DNA replication and enzymatic reactions involved in the amino acid synthesis [1-3]. Folate demand in pregnant women extremely increases because it is necessary for fetuses to grow and develop [4]. Folic acid cannot be synthesized by the human body and must be obtained from diet and supplements [5], and folic acid deficiency may result in neural tube defects (NTDs) [6,7]. NTDs are birth defects of the spine, spinal cord, or brain that originate during embryonic development. The most common NTDs are spinal cord and spina bifida and anencephaly [8]. Folic acid supplementations for pregnant women are an effective primary care-relevant preventive intervention [9]. America and many other countries issued the regulations to require amending the standards of several grain products and vegetable by folic acid addition $[7,10,11]$. As recommended, all women of childbearing age should take
400 to 800 micrograms folic acid per day during the periconceptional and pregnancy $[9,12-16]$. Women who had a fetus diagnosed as affected by a neural tube defect or have given birth to a baby with a neural tube defect have an increased risk and should be administered high-dose supplementation (5 mg folic acid daily) [17].

As inactive form, folic acid must be converted by MTHFR to tetrahydrofolic acid and 5-methyltetrahydrofolate (5-MTHF) for regulating the metabolism of folate and homocysteine [5,18-20]. It is well known that MTHFR C677T(rs1801133) genetic variation leads to enzyme activity reducing, and finally, influences susceptibility to occlusive vascular diseases, NTDs, colon cancer and acute leukemia [21-24]. Mutant homozygote (TT genotype) which significantly elevated plasma homocysteine level is a crucial hereditary risk factor in the development of some diseases, and constitutes approximately $20 \%$ in northern China $[25,26]$. Methionine synthase reductase (MTRR) which keeps sufficient levels of methylcob(III)alamin, the activated cofactor for methionine synthase, catalyzes homocysteine remethylation to methionine [27,28]. One major allelic variant of MTRR A66G (rs1801394) act as a predisposing factor contributing hyperhomocysteinemia [29]. According to Walker (1999), the mean 
Citation: Song C, Song W, Bao J, Luo J, Zuo X, et al (2018) Association between Decreased Plasma Folate Levels and MTHFR C677T, and MTRR A66G Gene Polymorphisms as Determinants for Elevated Total Homocysteine Concentrations in Pregnant Women. Hereditary Genet Curr Res 7: 193. doi:10.4172/2161-1041.1000193

Page 2 of 6

homocysteine concentration was $5.6 \mu \mathrm{mol} / \mathrm{L}$ (95\% confidence interval 3.9-7.3) at 8-16 weeks' gestation [30]. Elevated serum homocysteine of the first trimester is correlated with history of pregnancy losses, vascular-related complications of pregnancy, and preterm birth [31]. Notably, the 66GG genotype increased the risk of NTDs pregnancy outcomes in women with low vitamin B12 levels or when the MTHFR C677T mutation is also present $[27,28,32]$. In addition, the risk of bearing Down's syndrome babies increased among the women who carry both the MTHFR 677T and MTRR 66G mutations genes [33,34]. Our objective was to examine the association between gene polymorphisms of MTHFR C677T and MTRR A66G with levels of plasma folate and tHcy.

\section{Materials and Methods}

\section{Study subjects}

143 eligible pregnant women (the mean age is $29.7 \pm 11.3$ years, range: $18-43$ years) were recruited. All of them were Han people and had the same or the similar dose of folic acid supplementation $(0.4 \mathrm{mg}$ per day). Women with Alcohol consumption, smoking habits, and those with metabolic disorders, renal insufficiency, hemolytic disorders, and malignancies et al. which may lead to decreasing serum folate level were excluded. All subjects were recruited from the department of Obstetrical in First People's Hospital of Kunming during the period from July 1, 2016 to February 28, 2017. Ethical approval for the study was obtained by the Ethics Committee of the Kunming first people hospital Research Center at May 18, 2016 and the version number is 201605182 . Informed consents were acquired from all participants.

\section{Genotype analysis}

Blood samples were collected in tubes containing $200 \mu \mathrm{L}$ of $2 \%$ EDTA and stored at $-80^{\circ} \mathrm{C}$ or colder until further analysis. Genotyping for MTHFR C677T and MTRR A66G single nucleotide polymorphisms (SNP) gene mutations were performed by polymerase chain reaction (PCR) followed by restriction fragment length polymorphism (RFLP) and agarose gel electrophoresis. Data were analyzed using Lasergene. The MTHFR C677T polymorphism was detected using sequences (forward: 5'CCCTATTGGCAGGTTACCCC $\quad-3$ 'and reverse: 5'TCTGGGAAGAACTCAGCGAAC -3') and HaeIII endonuclease in PCR-RFLP assays. MTRR A66G was genotyped using primers (forward: 5'-CGGATCATTTGGGGAGCTTG -3' and reverse: 5'TGTAACGGCTCTAACCTTATCGG $-3^{\prime}$ ) and NdeI restriction enzyme.

\section{Plasma folate and total homocysteine concentrations measurements}

Plasma folate was determined by Semi-quantitative chemiluminescent microparticle immunoassay (ARCHITECT i1000SR immunoassay analyzer, Abbott Laboratories, Abbott Park, IL, USA) using ARCHITECT Folate Reagent Kit and ARCHITECT Homocysteine Reagent Kit (Abbott Laboratories, Abbott Park, IL, USA), respectively $[35,36]$. Serum tHcy concentration was measured by high-performance liquid chromatography and fluorometric detection following reduction, deproteinization, and derivatization with the fluorophore SBDF (ammonium 7-fluorobenzo-2- oxa-1,3diazole-4-sullfonate).

\section{Statistical methods}

Data analysis was performed by IBM SPSS Statistics 22.0 (SPSS Inc., IBM Corporation, Chicago, IL, USA) and GraphPad Prism 7.03 software (GraphPad Software Inc., La Jolla, CA, USA). Genotype distributions and allele frequencies of MTHFR C677T and MTRR $A 66 G$ of participants was determined, and their $95 \%$ confidence intervals (CI) were calculated. Hardy-Weinberg equilibrium was determined for all of the genotypes using $\chi^{2}$ testing. Continuous variables including age, blood parameters (folate and tHcy) and gestational weeks were calculated as mean \pm S.D., and analyzed using one-way ANOVA, Pearson's correlation coefficient, and Tukey's test. The significance threshold was set at 0.05 . Because the distribution of plasma values of tHcy had a positive skew, analyses were carried out after logarithmic transformation, and back-transformed results are shown.

\section{Results}

The genotype distributions of the MTHFR C677T polymorphisms was in Hardy-Weinberg equilibrium $(\mathrm{P}=0.668773)$. Genotype distributions of the MTHFR C677T and MTRR A66G polymorphism of the 143 Han women of Yunnan Province were analyzed: 50 (35\%) subjects were CC, 67 (47\%) were CT, and $26(18 \%)$ subjects were TT; 63 (44\%) subjects were AA, 51 (36\%) subjects were AG, and 29 (20\%) subjects were GG. The allele frequencies of MTHFR 677T and MTRR $66 \mathrm{G}$ were $41.6 \%$ and $38 \%$, respectively (Table 1). As shown in Figure la, there was a significant effect of $C 677 T$ polymorphism on plasma folate levels, with homozygous wild-type objects having higher folate levels than either of the other two genotype groups $(\mathrm{P}=0.000)$.

\begin{tabular}{|c|c|c|c|c|}
\hline Genotype & $\mathbf{n}$ & $\begin{array}{l}\text { Genotype } \\
\text { Distributions (\%) }\end{array}$ & $\begin{array}{l}\text { Allele } \\
\text { frequency (\%) }\end{array}$ & $95 \% \mathrm{Cl}^{*}$ \\
\hline \multicolumn{2}{|c|}{ MTHFR C677T } & - & $\mathrm{T}$ of $\mathrm{C} 677 \mathrm{~T}$ & - \\
\hline $\mathrm{CC}$ & 50 & $35 \%$ & \multirow{3}{*}{42} & \multirow{3}{*}{$P=0.668773$} \\
\hline CT & 67 & $47 \%$ & & \\
\hline TT & 26 & $18 \%$ & & \\
\hline \multicolumn{2}{|c|}{ MTRR A66G } & - & $\mathrm{G}$ of $\mathrm{A} 66 \mathrm{G}$ & - \\
\hline $\mathrm{AA}$ & 63 & $44 \%$ & \multirow{3}{*}{38} & \multirow{3}{*}{$P=0.003528$} \\
\hline$A G$ & 51 & $36 \%$ & & \\
\hline GG & 29 & $20 \%$ & & \\
\hline \multicolumn{5}{|c|}{$\mathrm{N}$ : The Number of Subjects in Each Group. ${ }^{*}$ Chi-squared test. } \\
\hline
\end{tabular}

Table 1: Genotype Distributions, and allele frequencies of the MTHFR C677T and MTRR A66G polymorphisms.

According to the relationship between genotypes and tHcy levels, the significant difference of tHcy levels between CC and TT $(\mathrm{P}=0.041)$ was observed (Figure 1b). No statistical significance was found between MTRR A66G gene polymorphism and plasma folate concentrations ( $\mathrm{P}=0.506,0.167$ and 0.424 , respectively) (Figure $1 \mathrm{c})$. In contrast, tHcy levels significant differences were observed between AA vs. AG and GG (Figure 1d). Plasma folate concentrations were negatively correlated with tHcy levels (Pearson's correlation coefficient $\mathrm{r}=-0.358, \mathrm{P}=0.000012$ ). 
Citation: Song C, Song W, Bao J, Luo J, Zuo X, et al (2018) Association between Decreased Plasma Folate Levels and MTHFR C677T, and MTRR A66G Gene Polymorphisms as Determinants for Elevated Total Homocysteine Concentrations in Pregnant Women. Hereditary Genet Curr Res 7: 193. doi:10.4172/2161-1041.1000193

Page 3 of 6

With the increase of gestational weeks, the levels of plasma folate rose in the first trimester and then fell in the second (Figure 2a). While there was a downtrend between gestational weeks and tHcy levels (Figure 2b).
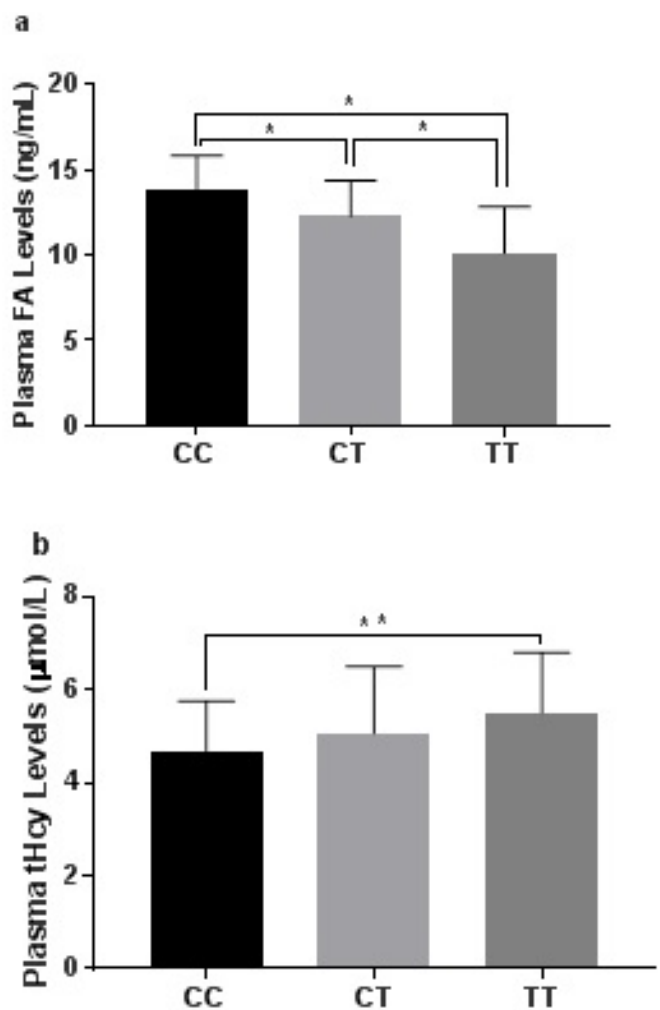
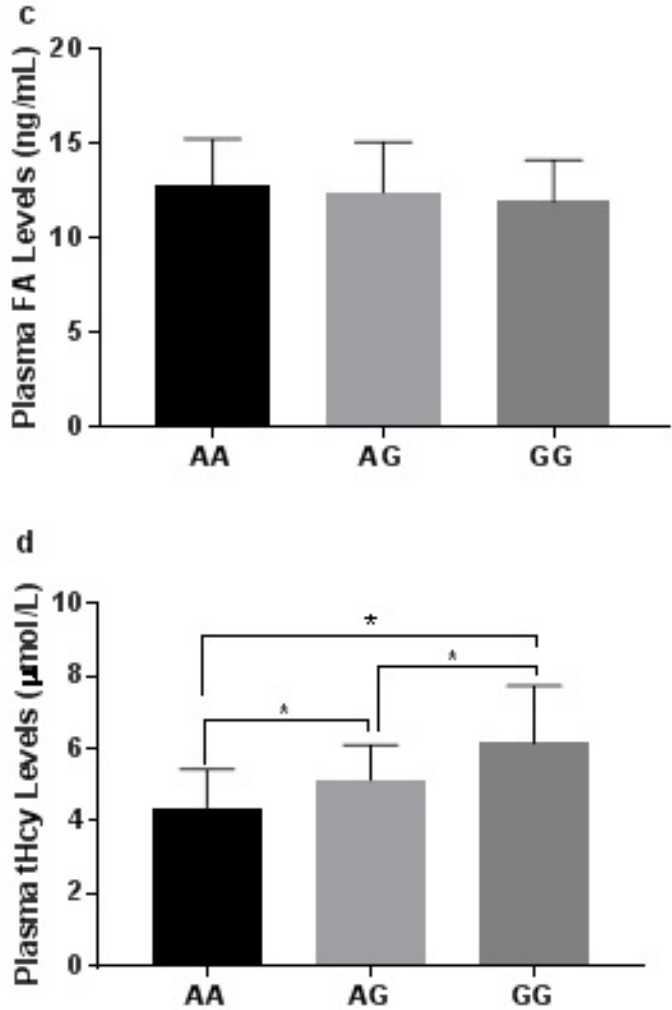

Figure 1: Plasma folate and tHcy levels varieties in different genotypes $(\mathrm{n}=143, \overline{\mathrm{x}} \pm \mathrm{s})$. a, b: Association of plasma folate and tHcy concentrations with MTHFR C677T polymorphism; c, d: Association of plasma folate and tHcy concentrations with MTRR A66G polymorphism. ${ }^{\star} \mathrm{p}<0.01,{ }^{* *} \mathrm{p}<0.05$.
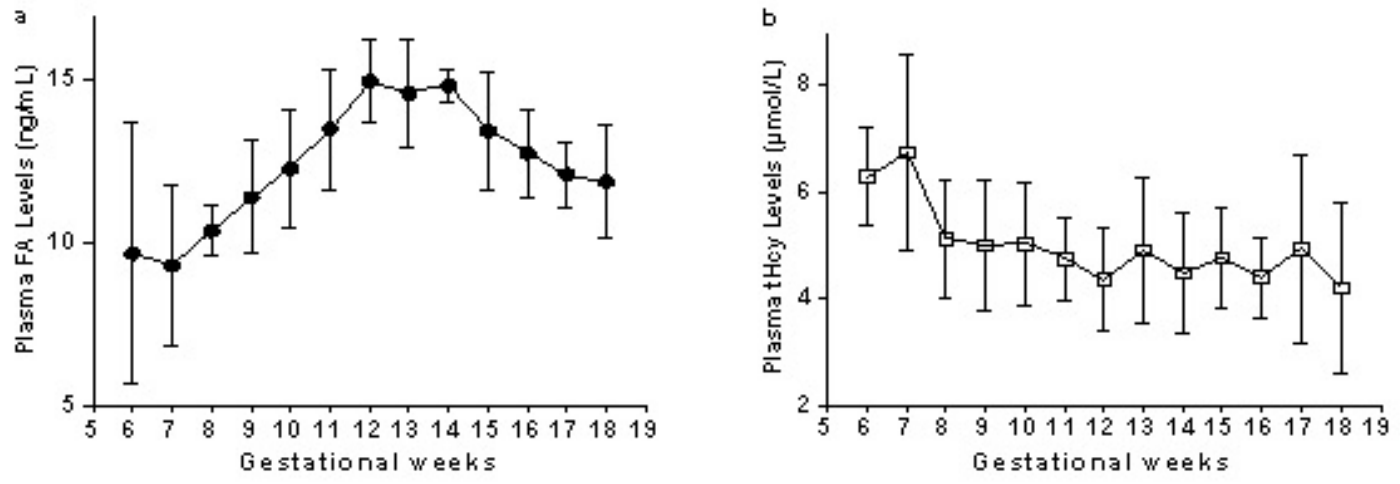

Figure 2: Mean Plasma folate and tHcy level trends changed along with increasing of gestational weeks. (a) Plasma FA concentrations rose markedly from the 7 th week and reached a peak during the 12 th week. Subsequently, a steady downward trend from the 14th to 18 th week was observed. (a) Plasma tHcy levels experienced a downward trend along with gestational weeks. 
Citation: Song C, Song W, Bao J, Luo J, Zuo X, et al (2018) Association between Decreased Plasma Folate Levels and MTHFR C677T, and MTRR A66G Gene Polymorphisms as Determinants for Elevated Total Homocysteine Concentrations in Pregnant Women. Hereditary Genet Curr Res 7: 193. doi:10.4172/2161-1041.1000193

Page 4 of 6

Plasma tHcy concentrations gradually dropped from the 7th to 12 th week along with the progress of pregnancy, and then there were an alternating upward and downward variations at successive weeks (Figure 2b).

The effects of the combination of genotypes for MTHFR C677T and MTRR A66G polymorphisms on folate and tHcy concentrations are shown in Table 2.

\begin{tabular}{|l|l|l|}
\hline $\begin{array}{l}\text { MTHFR C677T/ } \\
\text { MTRR A66G }\end{array}$ & $\begin{array}{l}\text { Plasma Folate } \\
\text { Levels* }(\mathbf{n g} / \mathbf{m L})\end{array}$ & tHcy ${ }^{\Psi}(\mathbf{m m o l} / \mathbf{L})$ \\
\hline CC/AA $(n=25)$ & $13.65 \pm 2.01^{\mathrm{a}}$ & $4.33 \pm 0.81^{\mathrm{a}}$ \\
\hline CC/AG $(n=16)$ & $14.20 \pm 1.94^{\mathrm{b}}$ & $4.63 \pm 1.07^{\mathrm{b}}$ \\
\hline CC/GG $(n=9)$ & $14.01 \pm 1.76^{\mathrm{c}}$ & $5.82 \pm 1.04^{\mathrm{a}, \mathrm{c}}$ \\
\hline CT/AA $(n=28$ & $13.09 \pm 1.82^{\mathrm{d}}$ & $4.16 \pm 0.82^{\mathrm{c}, \mathrm{d}}$ \\
\hline CT/AG $(n=23)$ & $12.18 \pm 2.25^{\mathrm{e}}$ & $5.35 \pm 0.90^{\mathrm{a}, \mathrm{d}}$ \\
\hline CT/GG $(n=16)$ & $11.10 \pm 1.69^{\mathrm{a}, \mathrm{b}, \mathrm{c}}$ & $6.27 \pm 1.86^{\mathrm{a}, \mathrm{b}, \mathrm{d}}$ \\
\hline TT/AA $(n=10)$ & $9.45 \pm 2.88^{\mathrm{a}, \mathrm{b}, \mathrm{c}, \mathrm{d}, \mathrm{e}}$ & $5.20 \pm 1.66$ \\
\hline TT/AG $(n=12)$ & $10.49 \pm 2.89^{\mathrm{a}, \mathrm{b}, \mathrm{c}, \mathrm{d}}$ & $5.47 \pm 0.65^{\mathrm{a}, \mathrm{d}}$ \\
\hline TT/GG $(n=4)$ & $10.73 \pm 1.65$ & $6.43 \pm 1.62^{\mathrm{a}, \mathrm{d}}$ \\
\hline
\end{tabular}

thcy: Total Plasma Homocysteine Concentration. N: The Number of Subjects in Each Group.

*One-way ANOVA performed. $F(8,134)=8.329, p<0.0005 ; \psi$ One-way ANOVA performed on the log-transformed variables. $F(8,134)=7.920, p<0.0005$;

Values in a row with different superscript letters are significantly different, $p<0.05$ (Tukey's test).

Table 2: Association analysis of plasma folate and tHcy concentrations according to the combination of genotypes for MTHFR C677T and MTRR A66G gene polymorphisms.

\begin{tabular}{|l|l|l|l|}
\hline $\begin{array}{l}\text { Age } \\
(\text { years })\end{array}$ & $\begin{array}{l}\text { Samples } \\
(\mathbf{n}, \%)\end{array}$ & $\begin{array}{l}\text { Plasma Folate } \\
\text { Levels }(\mathbf{x} \pm \mathbf{s}, \mathbf{n g} / \mathrm{mL})\end{array}$ & $\begin{array}{l}\text { tHcy Levels } \\
(\mathbf{x} \pm \mathbf{s}, \boldsymbol{\mu m o l} / \mathbf{L})\end{array}$ \\
\hline$<25$ & $13(9 \%)$ & $11.43 \pm 3.20$ & $5.03 \pm 1.41$ \\
\hline $25 \sim$ & $67(47 \%)$ & $12.63 \pm 2.47$ & $5.19 \pm 1.51$ \\
\hline $30 \sim$ & $38(27 \%)$ & $12.51 \pm 2.48$ & $4.63 \pm 0.82$ \\
\hline $35 \sim$ & $22(15 \%)$ & $12.33 \pm 2.32$ & $5.04 \pm 1.20$ \\
\hline $40 \sim$ & $3(2 \%)$ & $13.70 \pm 2.07$ & $5.68 \pm 2.05$ \\
\hline
\end{tabular}

tHcy: Total Plasma Homocysteine Concentration. N: The Number of Subjects in Each Group.

Table 3: Plasma folate and total homocysteine levels varieties in different age women ( $\mathrm{n}=143, \overline{\mathrm{x}} \pm$ S.D.).

The one-way ANOVA indicated that pregnant women with the MTHFR 677TT/MTRR 66AA haplotype had lower serum folate concentrations than those with MTHFR 677CC/MTRR 66AA, MTHFR 677CC/MTRR 66AG, MTHFR 677CC/MTRR 66GG, MTHFR 677CT/MTRR 66AA, MTHFR 677CT/MTRR 66AG, and MTHFR 677TT/MTRR 66AG. While the MTHFR 677TT/MTRR 66GG haplotype had higher tHcy concentrations than MTHFR
677CC/MTRR 66AA, MTHFR 677CC/MTRR 66GG, MTHFR 677CT/ MTRR 66AA, MTHFR 677CT/MTRR 66AG, MTHFR 677CT/MTRR 66GG and MTHFR 677TT/MTRR 66AG. No significant difference was observed between age and maternal plasma folate and homocysteine levels (Table 3).

\section{Discussion}

Epidemiological evidence has revealed that variety of factors contributes to the risk of adverse pregnancy outcomes. These factors include genetic variation, maternal nutrition and immunological responses, periconceptional intake of folic acid antagonists (trimethoprim, carbamazepine, phenobarbital, phenytoin, et al.) [37-39]. Folate is fundamental for nucleic acid synthesis and needed for homocysteine metabolism and methylation reactions [40]. Maternal plasma folate deficiency is associated with an increased the total plasma homocysteine which is strongly related to adverse pregnancy outcomes and other diseases [24,41,42].

In this paper, we provide evidence those polymorphisms of MTHFR C677T and MTRR A66G are associated with plasma folate and tHcy levels. The results showed that the $M T R R A 66 G$ polymorphism alone was not related to plasma folate concentrations but significantly related to circulating tHcy levels, and this finding was similar to the pioneering studies of Barbosa et al. 40 and Gaughan et al. 27, respectively. However, exactly the reverse, our study indicated that 66GG, not 66AA significantly elevating tHcy. This may be due to sex and race varieties. 43 There was a significant difference in tHcy levels among 66AA, 66AG, and 66GG $(4.39 \pm 1.04 \mu \mathrm{mol} / \mathrm{L}, 5.15 \pm 0.96$ $\mu \mathrm{mol} / \mathrm{L}, 6.15 \pm 1.58 \mu \mathrm{mol} / \mathrm{L}$, AA vs.AG, $\mathrm{P}=0.001$; AA vs.GG, $\mathrm{P}=0.000$; AG vs.GG, $\mathrm{P}=0.000$, respectively). Our results showed that the $M T R R$ 66GG genotype confers the relative risks of elevated tHcy. It seemed that MTRR A66G gene mutation contributed to lower plasma folate levels $(12.73 \pm 2.52 \mathrm{ng} / \mathrm{mL}, 12.42 \pm 2.67 \mathrm{ng} / \mathrm{mL}, 11.95 \pm 2.17 \mathrm{ng} / \mathrm{mL})$, although no significant differences were observed.

A possible explanation for this might be that the sample size is too small. In our study, the $\mathrm{T}$ allele frequency was $41.5 \%$ and individuals with variant allele $(\mathrm{T})$ significantly decreased plasma folate concentration (CC: $13.85 \pm 1.93 \mathrm{ng} / \mathrm{mL}, \mathrm{CT}: 12.34 \pm 2.10 \mathrm{ng} / \mathrm{mL}$, TT: $10.16 \pm 2.65 \mathrm{ng} / \mathrm{mL}$, respectively, $\mathrm{P}=0.000$ ). In addition, the subjects with TT genotype had significantly higher tHcy levels than those CC genotype $(5.44 \pm 1.32 \mu \mathrm{mol} / \mathrm{L}$ vs. $4.67 \pm 1.07 \mu \mathrm{mol} / \mathrm{L}$, respectively; $\mathrm{P}=0.010)$. The results were consistent with the previous studies $[24,43,44]$. Because the prevalence $(19 \%)$ of $677 \mathrm{TT}$ genotype is high in China, the risk of exposure to plasma folate deficiency, resultant hyperhomocysteinemia, and adverse pregnancy outcome may elevate [45-47].

The most interesting finding was that plasma folate concentrations rose markedly from the 7th week and reached a peak during the 12th week. Subsequently, a steady downward trend from the 14th to 18th week was observed (Figure 2a). Meanwhile, our data indicated that the plasma tHcy concentrations gradually dropped from the 7th to 12th week along with the progress of pregnancy, and then there were alternating upward and downward variations at successive weeks (Figure 2b).

Although both plasma folate and tHcy levels are significantly different in pregnant women than non-pregnancy women [48], no statistical significances were observed between first trimester and second trimester with plasma folate and tHcy levels. No previous study has investigated the relationship between plasma folate levels tendency 
Citation: Song C, Song W, Bao J, Luo J, Zuo X, et al (2018) Association between Decreased Plasma Folate Levels and MTHFR C677T, and MTRR A66G Gene Polymorphisms as Determinants for Elevated Total Homocysteine Concentrations in Pregnant Women. Hereditary Genet Curr Res 7: 193. doi:10.4172/2161-1041.1000193

Page 5 of 6

and gestational weeks. This is an important issue for future research. Moreover, our study indicated that there was a significant negative correlation between plasma tHcy and folate levels ( $\mathrm{r}=-0.358$, $\mathrm{p}=0.000012$ ), independently of MTHFR C677T and MTRR A66G gene polymorphisms.

According to Finer and his colleagues' report, up to $42 \%$ of American women and girls got pregnant without intentions during 2011, and the neural tube closes completely by 28 days from conception $[37,49,50]$. This means that almost half of women and girls may not use sufficient folic acid supplements before and early pregnancy [51]. The prevalence of NTDs will not decrease whether or not folic acid administration after 7 or more weeks of gestation [52].

Previous intervention study recommended the reference interval of plasma/serum folate for adults is $2.5-20 \mathrm{ng} / \mathrm{mL}$ [53]. Although WHO has not given an appropriate cutoff for gestation, a consensus suggested a concentration for defining folate deficiency $(4 \mathrm{ng} / \mathrm{mL})$ [41]. Besides, Chinese government recommends all of the childbearing age women consuming $0.4 \mathrm{mg}$ folic acid daily, and the rate of NTDs has shown a declining trend [54-56]. However, compared with US women's plasma folate level, our data indicated that the plasma folate level was lower than the geometric mean $37.3 \mathrm{nmol} / \mathrm{L}$ [46,57]. In conclusion, as many pregnancies are unplanned, and taking the MTHFR C677T and $M T R R A 66 G$ polymorphisms and environmental factors into account, we recommend that health providers supply appropriate folic acid with or without multiple vitamin supplements to all childbearing age women based on their genotypes and vitamin status. Furthermore, additional investigation into the optimal dose is strongly recommended.

\section{Conclusion}

According to our study, The MTHFR C677T, MTRR A66G polymorphism and folate deficiency were significantly associated with elevated serum tHcy levels. The pregnancy of homozygous mutation of MTHFR 677TT and MTRR 66GG genes could induce the decrease of folate. Therefore, our research recommended that pregnant women with homozygous mutation of 677TT and 66GG genes should supply the appropriate dosage of folic acid based on their genotypes.

\section{Conflict of Interest}

The authors do not have any conflicts of interest concerning disclosure.

\section{Acknowledgements}

We thank Cangsang Song, Wenbin Song, Jinying Bao, Jing Luo, Xin Zuo and Ni An for their contribution to this work. Health and Family Planning Commission of Yunnan Province funded this work under Grant 2016NS331.

\section{References}

1. Fenech M (2012) Folate (vitamin B9) and vitamin B12 and their function in the maintenance of nuclear and mitochondrial genome integrity. Mutat Res 733: 21-33.

2. Moores CJ, Fenech M, O'Callaghan NJ (2011) Telomere dynamics: the influence of folate and DNA methylation. Ann N Y Acad Sci 1229: 76-88.

3. Bailey LB, Gregory JF (1999) 3rd. Folate metabolism and requirements. J Nutr 129: 779-782.
4. Greenberg JA, Bell SJ, Guan Y, Yu YH (2011) Folic acid supplementation and pregnancy: more than just neural tube defect prevention. Rev Obstet Gynecol 4: 52-59.

5. Lucock M (2000) Folic acid: nutritional biochemistry, molecular biology, and role in disease processes. Mol Genet Metab 71: 121-138.

6. Hayati AR, Zainal AI, Tan GC, Ong LC, Khoo TB (2008) MTHFR C677T polymorphism as a risk factor of neural tube defects in Malay: a case control study. Med J Malaysia 63: 379-383.

7. De Wals P, Tairou F, Van Allen MI, Uh SH, Lowry RB, et al. (2007) Reduction in neural-tube defects after folic acid fortification in Canada. N Engl J Med 357: 135-142.

8. Greene ND, Copp AJ (2014) Neural tube defects. Annu Rev Neurosci 37: 221-242.

9. Viswanathan M, Treiman KA, Kish-Doto J, Middleton JC, CokerSchwimmer EJ, et al. (2017) Folic acid supplementation for the prevention of neural tube Defects: An updated evidence report and systematic review for the US preventive services task force. JAMA 317: 190-203.

10. Honein MA, Paulozzi LJ, Mathews TJ, Erickson JD, Wong LY (2001) Impact of folic acid fortification of the US food supply on the occurrence of neural tube defects. JAMA 285: 2981-2986.

11. Bower C, Stanley FJ (2004) Case for mandatory fortification of food with folate in Australia, for the prevention of neural tube defects. Birth Defects Res A Clin Mol Teratol 70: 842-843.

12. Jacques PF, Selhub J, Bostom AG, Wilson PW, Rosenberg IH (1999) The effect of folic acid fortification on plasma folate and total homocysteine concentrations. N Engl J Med 340: 1449-1454.

13. Recommendations and reports: Morbidity and mortality weekly report (1992) Centers for Disease C. Recommendations for the use of folic acid to reduce the number of cases of spina bifida and other neural tube defects. 41: 1-7.

14. Berry RJ, Li Z, Erickson JD, Li S, Moore CA, et al. (1999) Prevention of neural-tube defects with folic acid in China. China-U.S. collaborative project for neural tube defect prevention. N Engl J Med 341: 1485-1490.

15. Mills JL, McPartlin JM, Kirke PN, Lee YJ, Conley MR, et al. (1995) Homocysteine metabolism in pregnancies complicated by neural-tube defects. Lancet 345: 149-151.

16. Group MVSR (1991) Prevention of neural tube defects: results of the Medical Research Council Vitamin Study. MRC Vitamin Study Research Group. Lancet 338: 131-137.

17. WHO (2017) Periconceptional folic acid supplementation to prevent neural tube defects.

18. Bagley PJ, Selhub J (1998) A common mutation in the methylenetetrahydrofolate reductase gene is associated with an accumulation of formylated tetrahydrofolates in red blood cells. Proc Natl Acad Sci USA 95: 13217-13220.

19. Ueland PM, Hustad S, Schneede J, Refsum H, Vollset SE (2001) Biological and clinical implications of the MTHFR C677T polymorphism. Trends Pharmacol Sci 22: 195-201.

20. Mahmood L (2014) The metabolic processes of folic acid and Vitamin B12 deficiency. J Health Res Rev 1: 5-9.

21. Goyette P, Sumner JS, Milos R, Duncan AM, Rosenblatt DS, et al. (1994) Human methylenetetrahydrofolate reductase: isolation of cDNA mapping and mutation identification. Nat Genet 7: 551.

22. Weisberg I, Tran P, Christensen B, Sibani S, Rozen R (1998) A second genetic polymorphism in methylenetetrahydrofolate reductase (MTHFR) associated with decreased enzyme activity. Mol Genet Metab 64: 169-172.

23. Harmon DL, Doyle RM, Meleady R, Doyle M, Shields DC, et al. (1999) Genetic analysis of the thermolabile variant of 5, 10methylenetetrahydrofolate reductase as a risk factor for ischemic stroke. Arterioscler Thromb Vasc Biol 19: 208-211.

24. Botto N, Andreassi MG, Manfredi S, Masetti S, Cocci F, et al. (2003) Genetic polymorphisms in folate and homocysteine metabolism as risk factors for DNA damage. Eur J Hum Genet 11: 671-678. 
Citation: Song C, Song W, Bao J, Luo J, Zuo X, et al (2018) Association between Decreased Plasma Folate Levels and MTHFR C677T, and MTRR A66G Gene Polymorphisms as Determinants for Elevated Total Homocysteine Concentrations in Pregnant Women. Hereditary Genet Curr Res 7: 193. doi:10.4172/2161-1041.1000193

Page 6 of 6

25. Wilcken B, Bamforth F, Li Z, Zhu H, Ritvanen A, et al. (2003) Geographical and ethnic variation of the $677 \mathrm{C}>\mathrm{T}$ allele of 5,10 methylenetetrahydrofolate reductase (MTHFR): findings from over 7000 newborns from 16 areas worldwide. J Med Genet 40: 619-625.

26. Frosst P, Blom HJ, Milos R, Goyette P, Sheppard CA, et al. (1995) A candidate genetic risk factor for vascular disease: a common mutation in methylenetetrahydrofolate reductase. Nat Genet 10: 111-113.

27. Gaughan DJ, Kluijtmans LA, Barbaux S, McMaster D, Young IS, et al. (2001) The methionine synthase reductase (MTRR) A66G polymorphism is a novel genetic determinant of plasma homocysteine concentrations. Atherosclerosis 157: 451-456.

28. Wilson A, Platt R, Wu Q, Leclerc D, Christensen B, et al. (1999) A common variant in methionine synthase reductase combined with low cobalamin (vitamin B12) increases risk for spina bifida. Mol Genet Metab 67: 317-323.

29. Laraqui A, Allami A, Carrie A, Coiffard AS, Benkouka F, et al. (2006) Influence of methionine synthase $(\mathrm{A} 2756 \mathrm{G})$ and methionine synthase reductase $(\mathrm{A} 66 \mathrm{G})$ polymorphisms on plasma homocysteine levels and relation to risk of coronary artery disease. Acta Cardiol 61: 51-61.

30. Walker MC, Smith GN, Perkins SL, Keely EJ, Garner PR (1999) Changes in homocysteine levels during normal pregnancy. Am J Obstet Gynecol 180: 660-664.

31. Mascarenhas M, Habeebullah S, Sridhar MG (2014) Revisiting the role of first trimester homocysteine as an index of maternal and fetal outcome. J Pregnancy 2014:1-6.

32. Medina MA, Amores-Sanchez MI (2000) Genetic basis of hyperhomocysteinemia. Mol Genet Metab 71: 478-480.

33. Hobbs CA, Sherman SL, Yi P, Hopkins SE, Torfs CP, et al. (2000) Polymorphisms in genes involved in folate metabolism as maternal risk factors for Down syndrome. Am J Hum Genet 67: 623-630.

34. O'Leary VB, Parle-McDermott A, Molloy AM, Kirke PN, Johnson Z, et al. (2002) MTRR and MTHFR polymorphism: link to Down syndrome? Am J Med Genet 107: 151-155.

35. Abbott (2008)ARCHITECT Homocysteine.

36. Abbott (2010) ARCHITECT Folate.

37. Blom HJ, Shaw GM, den Heijer M, Finnell RH (2006) Neural tube defects and folate: case far from closed. Nat Rev Neurosci 7: 724-731.

38. Hernandez-Diaz S, Werler MM, Walker AM, Mitchell AA (2000) Folic acid antagonists during pregnancy and the risk of birth defects. N Engl J Med 343: 1608-1614.

39. Hernandez-Diaz S, Werler MM, Walker AM, Mitchell AA (2001) Neural tube defects in relation to use of folic acid antagonists during pregnancy. Am J Epidemiol 153: 961-968.

40. Barbosa PR, Stabler SP, Machado AL, Braga RC, Hirata RD, et al. (2008) Association between decreased vitamin levels and MTHFR, MTR and MTRR gene polymorphisms as determinants for elevated total homocysteine concentrations in pregnant women. Eur J Clin Nutr 62: 1010-1021.

41. De Benoist B (2008) Conclusions of a WHO technical consultation on folate and vitamin B12 deficiencies. Food Nutr Bull 29: S238-244.
42. Scholl TO, Johnson WG (2000) Folic acid: influence on the outcome of pregnancy. Am J Clin Nutr 71: 1295S-1303S.

43. Hughes $\mathrm{K}$, Ong $\mathrm{CN}$ (2000) Homocysteine, folate, vitamin B12, and cardiovascular risk in Indians, Malays, and Chinese in Singapore. J Epidemiol Community Health 54: 31-34.

44. Ni J, Zhang L, Zhou T, Xu WJ, Xue JL, et al. (2017) Association between the MTHFR C677T polymorphism, blood folate and vitamin B12 deficiency, and elevated serum total homocysteine in healthy individuals in Yunnan Province, China. J Chin Med Assoc 80: 147-153.

45. Yang B, Liu Y, Li Y, Fan S, Zhi X, et al. (2013) Geographical distribution of MTHFR C677T, A1298C and MTRR A66G gene polymorphisms in China: findings from 15357 adults of Han nationality. PLoS One 8: e57917.

46. Ma R, Wang L, Jin L, Li Z, Ren A (2017) Plasma folate levels and associated factors in women planning to become pregnant in a population with high prevalence of neural tube defects. Birth Defects Res.

47. Wang X, Fu J, Li Q, Zeng D (2016) Geographical and ethnic distributions of the MTHFR C677T, A1298C and MTRR A66G gene polymorphisms in Chinese populations: A meta-analysis. PLoS One 11: e0152414.

48. Karim KMR, Parvin F, Ali L (2012) Plasma homocysteine, folate and vitamin B 12 in different trimester of pregnancy 2012: 11.

49. Roth C, Bjorke-Monsen AL, Reichborn-Kjennerud T, Nilsen RM, Smith GD, et al. (2013) Use of folic acid supplements in early pregnancy in relation to maternal plasma levels in week 18 of pregnancy. Mol Nutr Food Res 57: 653-660.

50. Finer LB, Zolna MR (2016) Declines in unintended pregnancy in the United States, 2008-2011. N Engl J Med 374: 843-852.

51. Wald NJ (2004) Folic acid and the prevention of neural-tube defects. N Engl J Med 350: 101-103.

52. Milunsky A, Jick H, Jick SS (1989) Multivitamin/folic acid supplementation in early pregnancy reduces the prevalence of neural tube defects. JAMA 262: 2847-2852.

53. Fischbach FT, Dunning MB (2009) A manual of laboratory and diagnostic tests. Wolters Kluwer Health/Lippincott Williams \& Wilkins, USA.

54. Zhao Y, Hao L, Zhang L, Tian Y, Cao Y, et al. (2009) Plasma folate status and dietary folate intake among Chinese women of childbearing age. Matern Child Nutr 5: 104-116.

55. Ren AG (2015) Prevention of neural tube defects with folic acid: The Chinese experience. World J Clin Pediatr 4: 41-44.

56. Meng Q, Zhang L, Liu J, Li Z, Jin L, et al. (2015) Dietary folate intake levels in rural women immediately before pregnancy in Northern China. Birth Defects Res A Clin Mol Teratol 103: 27-36.

57. Pfeiffer CM, Sternberg MR, Fazili Z, Lacher DA, Zhang M, et al. (2015) Folate status and concentrations of serum folate forms in the US population: National Health and Nutrition Examination Survey 2011-2. Br J Nutr 113: 1965-1977. 